\title{
Mão-de-obra indígena na Amazônia Colonial
}

\author{
JAMES O. SOUSA ${ }^{*}$
}

RESUMO: Uma das características marcantes do processo de conquista português na Amazônia foi a utilização da mão-de-obra indígena. Colonos, missionários e a Coroa portuguesa envolveram-se em constantes embates e também em conivências que definiram tragicamente o destino dos índios. Diversas leis, regimentos e decretos foram criados pelo Estado português, ao longo do período colonial, que refletiram o poder político dos interessados na proteção ou manutenção da mão-de-obra indígena, tais determinações jurídicas quando favoreciam os índios eram logo derrubadas, não cumpridas ou criavam-se brechas para justificar o aprisionamento e escravidão dos mesmos. As diferentes posturas adotadas pelas ordens religiosas, responsáveis por exercerem o contato com os índios, foram constantes na polêmica que instaurou-se nos confins amazônicos.

PALAVRAS-CHAVE: mão-de-obra indígena, leis e regimentos, escravidão, Pombal, missionários e mercedários.

\section{A IMPORTÂNCIA DA MÃO-DE-OBRA INDÍGENA}

O processo de conquista da Coroa portuguesa na região amazônica só tornou-se possível, em grande medida, devido à utilização da força de trabalho indígena, na construção de grande parte dos fortes, fortalezas, cidades e vilas; a oeste, ao sul e ao norte, através dos rios Tapajós, Madeira, Negro, Branco e Javari; na coleta do principal recurso econômico da Amazônia no período, o extrativismo das chamadas "drogas do sertão”, o qual exigia a penetração pela floresta e o seu profundo conhecimento, constituindo um fator depreciativo em relação à utilização do escravo africano, já que só o índio poderia suprir tais requisitos. (Beozzo, 1984, p. 28)

Criou-se toda uma problemática na América portuguesa e em sua metrópole em torno da legitimidade ou não da posse do índio e de seu papel entre missionários e colonos. A Coroa portuguesa, responsável por intermediar o conflito, muitas vezes acabou criando leis oscilantes, expressivas de suas sucessivas mudanças de posição em relação ao assunto ao longo do tempo, dadas principalmente as pressões dos colonos. A posição oscilante da Coroa prejudicou a situação do índio e mesmo sua sobrevivência no projeto de conquista português.

O objetivo deste artigo é sistematizar algumas leis e regimentos que determinaram as formas de obtenção do trabalho indígena, e suas práticas, legais ou 
ilegais, por parte de colonos, missionários e do Estado; mostrar alguns exemplos do trato que as ordens religiosas na Amazônia deram à força de trabalho indígena, seja no trabalho nas fazendas dos religiosos, seja na transferência dos índios para os colonos e Estado português que as mesmas em determinados momentos efetuaram.

\section{Processo de COLONIZAÇÃo E SITUAÇÃo ECONÔMICA do GRÃo-PARÁ}

Em seu livro Economia e Sociedade em Áreas Periféricas: Guiana Francesa e Pará, Ciro Flamarion Cardoso (1984, pp. 95/6) resume a história do povoamento do Pará, dividindo em três períodos sua época colonial. No primeiro período, desde a fundação de Belém (1616) a meados do século XVII, os fatos mais importantes foram a expulsão de franceses, holandeses e britânicos e as expedições de reconhecimento (em especial a de Pedro Teixeira, em 1637-39), sendo muito tênue o povoamento de europeus (e cafuzos nordestinos) e relativamente pequena a quantidade de índios postos a serviço da colonização. No segundo período, compreendido entre meados do século XVII a metade do século seguinte, assentou-se um estilo de economia e de povoamento baseado principalmente no extrativismo vegetal, nos apresamentos de índios e no aldeamento destes pelos missionários. Finalmente, no terceiro período, segunda metade do século XVIII, inaugurou-se, com a gradual aplicação das reformas de Pombal, a intensificação do povoamento do Pará, enquanto se destruía ou se modificava o sistema montado pelos missionários.

A perseguição e a escravização desenfreada dos índios pelos colonos era justificada pelos últimos com a sua própria “incapacidade financeira”, que os impedia de comprar escravos negros, bem mais caros que os índios. Para Ciro Flamarion, o atraso e a situação de pobreza do Grão-Pará, até a metade do século XVIII, eram incontestáveis:

Tudo confirma a impressão de pobreza, marasmo e abandono, numa colônia onde a atividade principal - a extração silvestre de "drogas do sertão" como o cacau, a salsaparilha, a baunilha, o pau-cravo, etc. - era puramente predatória [...] Um bom exemplo do atraso econômico é que só em 1748 decidiu a metrópole introduzir no Pará a economia monetária, efetivando-se tal medida em 1752 quando o Estado português providenciou o envio de dois mil reis; antes corriam como moeda o cacau, o cravo, a salsaparrilha, o açúcar, novelos de algodão etc. (1984, p. 98) 
No que se refere às relações de trabalho, o português colonizador na Amazônia manteve o mesmo posicionamento, em grande medida, do colonizador do Estado do Brasil: ambos se negaram ao trabalho braçal, transferido, em geral pela força, a outros grupos.

Quando não podia contar com o trabalho indígena, o branco colonizador não encontrava solução a não ser a importação de escravos africanos. Trabalhar, com suas próprias mãos, a terra amazônica, ou dela extrair, com seus próprios braços, os produtos naturais - as drogas do sertão - isso era coisa que não passava pela cabeça da quase totalidade dos portugueses residentes no Brasil. Afinal, o regime colonial fora implantado justamente para isso (Leonardi, 2000, p. 27).

\section{LEIS, REGIMENTOS E FORMAS DE ESCRAVIDÃO INDÍGENA}

A lei de 1595 previa um único motivo para escravizar o índio: somente a prisão, feita durante alguma guerra, e efetuada por ordem direta da Coroa (Handelman, 1937, p. 232). Os decretos de 1605, 1608 e 1609 suprimiram inteiramente a escravidão do índio, declarando por princípio a liberdade indígena e a igualdade dos seus direitos políticos ao dos brancos. Mas essas leis não puderam ser instauradas, devido à pressão dos colonos, os quais alegavam falta de mão-de-obra para continuar seus negócios. Já o decreto de 1611 estabeleceu que os índios aprisionados numa guerra aprovada pelas altas autoridades, civis ou eclesiásticas, promovida pelos próprios indígenas, portanto, na perspectiva da coroa, resgatados “do martírio dos seus compatriotas” - deviam ser escravizados (Idem). Essa lei perdurou até 1649, quando foi novamente restaurado o direito de liberdade e igualdade dos índios, estabelecido pelo decreto de 1609. Mas, devido à sua posição totalmente contrária aos pressupostos estabelecidos em 1649, os colonos de São Luís e de Belém pegaram em armas para impedir a efetivação dessa última lei.

Já a lei de 1655, profundamente influenciada por Antônio Vieira, exímio combatente da causa da liberdade indígena na região amazônica, estabeleceu com grande moderação sérios esforços para acomodar, de um lado, as vantagens materiais dos colonos, e de outro, a proteção dos índios. Apesar disso, a escravidão particular continuou a existir; em se tratando de índios prisioneiros de guerra, ela devia, inclusive, 
ser vitalícia e hereditária. A escravidão dos índios resgatados, contudo, devia durar somente cinco anos. Com essa lei a situação dos índios livres mudou, pois a fiscalização deles, antes atribuída a funcionários civis, foi designada aos jesuítas. A atuação dos funcionários civis era geralmente prejudicial aos “índios livres”, pois compactuavam com os colonos que os tinham sob guarda, fazendo os índios prestar serviços aos portugueses por prazos maiores que os estabelecidos (Ibidem).

O padre Antonio Viera nos concede um exemplo do que ocorria com os "índios livres":

Os índios que moram em suas aldeias com o título de livres são muito mais cativos que os que moram nas casas particulares dos portugueses, [os índios chamados livres] ficam em uma pior condição que os escravos, pois ordinariamente ocupam as lavouras de tabaco, que é o mais cruel trabalho de quantos há no Brasil (1912, p. 73).

Pela lei de 1655 foi organizado um tribunal que tinha como função sentenciar os índios apanhados, prisioneiros de guerra ou resgatados. Este tribunal era composto pelo governador do Estado, ouvidor-geral, vigário do Maranhão ou Pará, e pelos prelados de quatro ordens religiosas: carmelitas, franciscanos, mercedários e jesuítas (Bosi, 1992, p.142). Mas deve-se ressaltar que quase todos membros do tribunal estavam comprometidos com o sistema colonial e geralmente votavam pela escravidão vitalícia e hereditária por “guerra justa”. Vieira e o então governador, André Vidal - que apoiava os preceitos do padre jesuíta quanto à proteção dos índios -, geralmente viam-se derrotados, em particular, pelos mercedários e carmelitas. Vieira queixou-se ostensivamente do comportamento dos representantes dessas duas ordens:

O provincial do Carmo e o Comissário das Mercês votaram que todos esses índios fossem cativos. E o fundamento de seu voto foi porque todas as guerras que há entre esses índios do Maranhão eram justas, e sendo justas as guerras, todos os tomados nelas ficavam cativos, conforme a lei de sua Majestade. Em prova de serem justas todas as ditas guerras, acrescentou o comissário que ele o sabia por informação de religiosos da sua ordem e de outros dignos de fé (Vieira, 1992, p.26).

Segundo Nadia Farage (1991, p.30), o exame da legitimidade dos cativeiros era, via de regra, uma falácia, não só pela conivência dos missionários, como também pelos falsos testemunhos de membros da tropa e, principalmente, pelas ameaças feitas aos índios apresados, para que respondessem às perguntas do missionário atribuindo a si mesmos uma condição escrava, sob pena de maus-tratos e morte. Assim, a guerra 
escravizadora contra os índios teria a plena cobertura da lei. Georg Thomas (1981, pp 27 e 54) argumenta que a guerra justa era um conceito ao mesmo tempo teológico e jurídico, enraizado na luta entre cristãos e mouros e que, no bojo da expansão ultramarina ibérica, suscitou intenso e controvertido debate.

Duas parecem ter sido as questões centrais deste debate: quando e como seria justa a guerra, e, ainda, a esfera de competência para declará-la. Quanto ao primeiro ponto, uma posição seria a de que a guerra contra os infiéis era sempre justa, tendo por motivo a propagação da fé. Vozes discordantes, como, por exemplo, a do dominicano Francisco de Vitória, argumentavam que a não aceitação da conversão por parte do “selvagem” não era em si mesma justificativa para a guerra, mas anuíam com relação ao impedimento da propagação da fé e da circulação das gentes. O “desenfreio moral e, principalmente, o canibalismo dos índios sul-americanos também comparece como pontos possíveis para uma guerra justa, mas em geral com sérias objeções. Havia unanimidade, no entanto, com relação à guerra justa defensiva, ou seja, em caso de ataques dos índios aos portugueses” (Farage, 1991, p. 26). O fato é que a aplicação do conceito de guerra justa variou, não só ao sabor da discussão empreendida entre teólogos e juristas, mas também, e principalmente, devido a considerações econômicas e políticas conjunturais.

No que se refere às expedições de resgate dos “índios de corda”, a legislação da Coroa reconhecia a legalidade da compra dos índios condenados pelas tribos ao sacrifício ritual. O Estado português apenas tentou coibir as fraudes dos colonos e garantir que o resgate constituísse uma prática efetivamente espontânea por parte dos vendedores indígenas (Gorender, 1980, p. 142).

O conceito de resgate tem seu precedente no comércio português na África, já no século XV, sendo exercido no contato com os índios desde os primeiros anos da exploração da costa brasileira (Thomas, 1931, p.48). Erigido ao longo do período colonial, o resgate referia-se basicamente à compra, pelos portugueses, de prisioneiros de guerra entre as nações indígenas, entre os quais se incluíam os chamados "índios presos a corda”, ou “índios de corda”, referência à corda que os Tupis atavam aos pés de seus prisioneiros destinados a serem "devorados". Assim "resgatados” das mãos de seus captores, esses índios deviam a vida a quem os comprava, e eram obrigados a pagar com trabalho por tempo determinado, de acordo com o preço de compra (Farage, 1991, p. 28) Seriam legítimos escravos também, segundo parecer da Mesa de Consciência e 
Ordens datado de 1625, os filhos de cativos que, pela regra de descendência do grupo indígena, herdassem a condição escrava dos pais.

A compra dos escravos dos índios legitimamente havidos colocava, como se pode verificar, algum embaraço adicional, pois havia que se julgar a legitimidade daqueles cativeiros. A lei de 9.4.1655, explicitamente, regulava esse procedimento, designando os missionários e os cabos das escoltas para o "exame da justiça da guerra”. Esta mesma lei, no entanto, encarregava-se de fornecer a saída para tal embaraço, declarando que, nos casos em que se constatasse que a guerra não fora justa, restaria a possibilidade de resgatar tais cativos (Idem).

Mas o passo decisivo na instituição das tropas de resgate, segundo Nadia Farage, veio a ser dado mais tarde, com a lei de 28-4-1688, em que:

O próprio Estado tornava-se empresário dos resgates, que a partir de então seriam feitos pela Fazenda Real: duas tropas - uma para o Pará e outra para o Maranhão - deveriam ser anualmente enviadas ao sertão. A Fazenda Real forneceria 3000 réis para a compra de quinquilharias necessárias ao resgate de escravos, devendo ser empregados dois mil para o Pará e mil para o Maranhão (Farage, 1991, p. 29).

Cada índio escravizado seria taxado em 3000 réis, e a renda desses impostos formaria um fundo intitulado “Tesouro dos Resgates”, para ser aplicado em benefício das missões, de novas entradas, e de outros itens relativos à obtenção da mão-de-obra. $\mathrm{O}$ Estado intervinha, assim, como nota Sweet, (1974, p. 466) em seu próprio benefício, desde que sobre a venda de escravos resgatados por tropas oficiais era possível cobrar dízimos, enquanto o apresamento por particulares, no mais das vezes clandestino, deixava invariavelmente vazios os cofres régios.

Estivemos tratando de aspectos formais de arregimentação da mão-de-obra escrava, mas não podemos pecar por inocência, pois a escravização clandestina na Amazônia como um todo foi de muito maior porte do que a escravização efetuada pelas tropas de resgate oficiais e pelas tropas de guerra somadas. Segundo David Sweet (Idem, p. 688), quase todos os moradores que iam ao sertão voltavam trazendo escravos. Os funcionários das fortalezas, encarregados de controlar esse fluxo clandestino, em geral se deixavam subornar, quando não estavam eles próprios engajados no tráfico de escravos. E missionários assinavam registros em branco ou, cedendo às ameaças dos membros da tropa ou a seus próprios interesses, davam por escravos os que legalmente seriam livres. 
Já com referência ao pagamento de salários, associado a formas diversas de trabalho compulsório, a Coroa procurou legislar no sentido de estipular os períodos de trabalho indígena compulsório a serviço de particulares. Dentre as formas que o sistema assumiu, prevaleceu a seguinte:

Os índios, agremiados nas aldeias, sob administração de seus principais ou dos missionários, eram obrigados a trabalhar em cada ano seis meses alternadamente de dois em dois anos; os outros seis meses ficavam livres, para cuidarem de suas roças (Azevedo, 1901, p.139).

Contudo, em breve começaram a surgir abusos: nem os índios eram pagos, mesmo sendo seu salário baixo - duas varas de pano a cada mês - nem lhes era concedido o tempo de liberdade a que tinham direito. Retidos após o término legal do controle em poder dos patrões, passavam por escravos legítimos e, quando morria o chefe da família, o índio forro era enunciado em testamento como escravo legítimo (Idem).

Continuando a tratar das leis vemos, aqui mais um exemplo do posicionamento ambíguo da Coroa: pela lei de 1663, a fiscalização sobre as reduções indígenas voltava as câmaras de Belém e São Luís, e o cuidado das almas dos índios perdia o monopólio jesuíta, agora repartido entre as ordens. A escravidão desenfreada não tinha agora obstáculos, já que os membros escolhidos para a Câmara eram os mesmos interessados na escravidão. Totalmente contrária aos preceitos da lei anterior, a lei de 1680 suprimia quase que por completo a escravidão dos índios, declarava libertos todos os prisioneiros resgatados de tribos indígenas e ordenava que fossem agasalhados nos aldeamentos; somente os prisioneiros de guerra permaneciam escravos. A fiscalização temporal e das almas retornava assim ao monopólio dos jesuítas. Poucos anos mais tarde o rei voltou atrás e novamente concedeu o direito de escravizar os índios nos casos de "guerra justa”, com a justificativa que o plano de substituir o índio pelo escravo negro não dera certo, devido principalmente ao preço (Handelman, 1931, pp. 240/1).

Em 1686 foi implementado o chamado Regimento das missões. O Regimento fez crescer o poder das ordens religiosas, que passaram a ter não só importância no labor espiritual, mas também no político e temporal, das aldeias sob sua administração. Segundo Hoornaert, (1991, p. 88) a partir do Regimento, os acontecimentos se precipitaram e os missionários de diversas ordens adquiriram uma liberdade maior, uma força de contestação que o sistema não pôde suportar. Segundo Corcino Medeiros, 
(1998, p. 79) os religiosos puderam então obter a posse exclusiva das aldeias, com a exclusão dos moradores brancos e mestiços, e, além disso, o controle de toda a vida econômica e social das aldeias. Os missionários, portanto, passaram a funcionar como centro e articuladores de todas as atividades nas aldeias, e como intermediários entre as aldeias e o sistema colonial.

Com relação basicamente ao trabalho indígena, o Regimento prescreveu-lhes e o tempo de serviço, nas aldeias do Pará, de seis meses, e, nas do Maranhão, de quatro meses. As atividades foram organizadas de maneira que um terço da população indígena permanecia na aldeia, enquanto dois terços ficavam ao dispor das solicitações externas. (1998, p. 43) O Regimento perdurou, com pequenas modificações, até o ano de 1755, quando foi extinto pelo governo pombalino.

\section{Pombal e o Diretório}

Influenciado pelo pensamento ilustrado de outros países da Europa, Pombal promoveu um conjunto de transformações políticas na metrópole lusa e em suas colônias, tentando recuperar a economia portuguesa e modernizar as instituições nacionais, segundo Leonardi (1996, p. 237) até então dominadas ideologicamente pelo clero. A expulsão dos jesuítas em 1759 inseriu-se nesse contexto.

O Estado do Maranhão e Grão-Pará foi objeto privilegiado de atenção por parte do ministério pombalino. Uma forte razão para tanto era o recém-assinado Tratado de Madri, de 1750, que demarcou as possessões luso-espanholas na América; por esse tratado, Portugal obtivera mais ganhos territoriais em seus limites na parte norte da colônia. Para assegurar os ganhos territoriais e incrementar o comércio - e, portanto, os ganhos da Coroa e dos setores mercantis -, foram postas em prática três medidas articuladas: a formação da Companhia Geral de Comércio do Maranhão e Grão-Pará, para a comercialização da produção amazônica e a introdução sistemática de escravos africanos na colônia: o fim da escravidão indígena e a retirada do poder temporal dos missionários sobre os aldeamentos indígenas, seguida da expulsão dos jesuítas (Farage, 1991, p.74). 
Para Corcino Medeiros, o período pombalino representou a primeira experiência em bases econômicas para o povoamento e consolidação do domínio português no vasto território amazônico, pois

organizou em novos moldes o movimento mercantil e estimulou a produção comercial em larga escala. Foi assim que, além da intensificação da exploração dos cacaus nativos e da extração das drogas do sertão, surgiram grandes plantações de arroz, algodão, café e cacau (1998, p. 154).

Como uma das principais preocupações de Pombal foi a demarcação da Amazônia portuguesa, em detrimento das pretensões francesas e espanholas sobre ela, o índio ganhou importância como elemento representativo do Estado português na Amazônia. Ironicamente, era o mesmo elemento que havia dois séculos e meio sofria uma intensa pressão e era vitima de ações que levavam à perda de sua identidade sócioeconômica, religiosa e étnica.

A lei pombalina de 1755 declarou extinta a escravidão do índio e aboliu o poder temporal dos missionários sobre eles, colocando os indígenas sob o comando de funcionários públicos, chamados de "diretores das aldeias”. Mas foi realmente com a lei que estabeleceu o Diretório, publicada em 1757, que se modificou consideravelmente a política indigenista portuguesa no Brasil. Segundo Rita Heloisa de Almeida,

o Diretório continha 95 parágrafos, tratando de variadas questões, como: a civilização dos índios, problemas para o cultivo de terras, produção agrícola e comercialização, expedições para coleta de espécies nativas, relações de trabalho dos índios com os moradores, edificação de vilas, povoamento e manutenção dos povoados por meio dos descimentos, presença de brancos entre índios, casamento e, por fim, um delineamento do "diretor" - figura central neste novo procedimento que substituía os missionários (1997, p. 166).

Kenneth Maxwell trata a implementação do Diretório como um meio mais eficaz de garantir a posse territorial das áreas fronteiriças da América portuguesa:

Como não era humanamente possível obter o número de pessoas necessárias do próprio Portugal ou das ilhas adjacentes (Açores e Madeira) sem convertê-los completamente em desertos, era essência abolir todas as diferenças ente índios e portugueses [...] os índios, portanto, teriam que ser libertados da tutela religiosa para que se incentivasse a miscigenação entre portugueses e índios, para assegurar um crescimento continuo da população... (Maxwell, 1996, p. 53). 
De acordo com Victor Leonardi, há uma tendência historiográfica no Brasil que considera progressista a política pombalina, pelo fato de ela ter fortalecido o Estado em detrimento, supostamente do clero. Mas, para o autor, essa apreciação está cheia de malentendidos. Segundo Leonardi:

\begin{abstract}
No que diz respeito aos índios, é preciso perceber como a política pombalina não foi nada progressista. Pelo contrário: o Diretório tornou obrigatório o uso da língua portuguesa nas escolas e proibiu não só o uso das línguas de cada povo indígena como do nheengatu, língua geral. A europeização dos índios também foi buscada pela proibição de habitações indígenas tradicionais. [...] Essa legislação etnocêntrica permitiu o trabalho forçado, pois os diretores passaram a monopolizar os índios, concentrando-os em verdadeiras aldeias-currais, e fazendo-os trabalhar na extração de drogas do sertão (1996, pp. 237/8).
\end{abstract}

Para Kenneth Maxwell, (1996, p. 60) a implantação do Diretório e a substituição dos jesuítas por funcionários indicados pelo Estado - que tinham como objetivos abolir o isolacionismo religioso e impulsionar os índios à integração secular -, na realidade proporcionou os meios para justificar à desafortunada população indígena as formas mais extremas de exploração e abuso.

Corcino Medeiros dos Santos (1998, p. 169) argumenta que os índios foram mantidos em um sistema de exploração, mesmo que dentro de uma lei que se propunha liberal. Segundo o historiador, os diretores, ao invés de tutores e protetores, constituíram-se em carrascos dos índios, mantendo-os em troncos, em cárceres privados e castigando-os com açoites, além de muitas outras violências. Houve um esforço excepcional dos diretores em engajar os índios na produção de bens comerciáveis. Assim, tentou-se organizá-los nas expedições extrativistas, na caça, pesca, produção agrícola, etc. Mas, como o diretor retinha a sexta parte do produto das lavouras e do comércio dos índios, e sendo certo apenas o lucro da extração das drogas do sertão, o diretor empregava os indígenas quase que exclusivamente nessa última atividade, em detrimento das lavouras de sustento das mesmas povoações.

Os resultados esperados pelo Diretório, no que se refere à integração indígena, não foram muito animadores. As contínuas revoltas e fugas para a floresta marcaram o período, numa demonstração da resistência dos povos indígenas contra o esforço de integrá-los à sociedade colonial e à economia internacional à maneira pombalina.

Outro aspecto que poderíamos citar, dentre as conseqüências negativas do Diretório para a população indígena, foram as constantes epidemias que mataram uma 
quantidade considerável de índios. Somente entre os anos de 1779 e 1781, morreram cerca de quinze mil índios em decorrência de bexiga, sarampo e sarampo grande. Tais epidemias originaram-se do contato entre os brancos e os índios nas aldeias, imprescindível no projeto pombalino (BNRJ, 21.1.1, N $\mathrm{N}^{\mathrm{0}} 10$ ). Essas perdas populacionais acabaram tendo ressonância na produção das povoações, aumentando a demanda da mão-de-obra. Tal fator reforçou o não cumprimento das intenções do Diretório, no sentido de iniciar os índios nas escolas publicas, fixar-lhes turnos de trabalho e assegurar-lhes horas destinadas a seus interesses particulares, fator somado, como já visto, à má vontade dos diretores das aldeias. Conforme todos os exemplos dados pelos autores, apesar de propor rupturas, o Diretório acabou reforçando as ações colonizadoras anteriores. Foi extinto no ano de 1798, encerrando a legislação pombalina referente aos índios.

Independente das leis, a problemática dos direitos dos índios no Brasil sempre movimentou mecanismos burocráticos de grande proporção. Beatriz Perrone Moisés tenta expor como se dava esta organização:

O principal documento legal eram os regimentos dos governadores gerais. O rei os assinava, assim como as Cartas Régias, leis [etc] auxiliado por corpos consultivos dedicados a questões coloniais. (Mesa de Consciência e Ordens, Conselho das Índias, Conselho Ultramarino). Estes emitiam pareceres que podiam, e costumavam ser, sancionados pelo rei, passando a ter valor legal ... Para o exame de questões específicas que exigiam conhecimentos locais de que a metrópole não dispunha, criaram-se as Juntas formadas por autoridades coloniais e religiosos. Entre as quais a mais importante, a Junta das Missões (Moisés, p. 192, pp. 116-117).

O fato é que mesmo quando determinadas leis defendiam os índios de forma acentuada, os colonos e alguns religiosos não as cumpriam, e o Estado costumeiramente não tomava medidas eficazes para garantir a efetivação das leis. A burocracia construída por Portugal para tratar de assunto tão delicado parece não só ter sucumbido ante aos interesses imediatos dos colonizadores, como até, em certos momentos, reforçado estes últimos. 


\section{MERCEDÁRIOS E DEMAIS ORDENS RELIGIOSAS NA PROBLEMÁTICA DA MÃO-DE- OBRA INDÍGENA NA AMAZÔNIA COLONIAL}

Na Amazônia, as ordens foram distribuídas pelo Estado português da seguinte forma, no ano de 1693: os jesuítas espalharam-se pelas áreas próximas ao Tapajós e ao Madeira, enquanto os carmelitas estabeleceram-se ao longo do Solimões, do rio Negro e do rio Branco e os mercedários fixaram-se nas imediações dos rios Urubu e Uatumã. A partir do ano de 1720, segundo fonte do Arquivo Público do Pará (APP, 231, p.130), o número de índios aldeados era de 54.264.

Para Beatriz Perrone (1992, p.120), as ordens religiosas acabaram detendo uma considerável concentração de índios em suas missões e, em alguns momentos, seja por determinação da lei ou por pressão do Estado português, acabavam cedendo alguns índios para a Coroa ou para os colonos. Convencendo os índios a irem para os chamados aldeamentos, os religiosos desenvolviam um importante papel para o projeto colonial, pois efetuavam a conversão do gentio, a ocupação e a defesa territorial e, mesmo que não o desejassem, criavam uma constante reserva de mão-de-obra para o desenvolvimento econômico da colônia.

O principal mecanismo de contato com os índios, que ficavam sob responsabilidade irrestrita dos missionários, no estabelecimento das comunicações iniciais, eram os chamados “descimentos”. Estes eram concebidos como

Deslocamento de povos inteiros para novas aldeias próximas aos estabelecimentos portugueses. Devem resultar da persuasão exercida por tropas de descimento lideradas ou acompanhadas por um missionário, sem qualquer tipo de violência - trata-se de convencer os índios de "sertão" de que é de seu interesse aldear-se junto aos portugueses, para sua própria proteção e bem - estar ... A obrigatoriedade da presença de missionários junto ás tropas de descimento é expressa pela lei de 1587. [ o motivo ] o conhecimento da língua e o fato de o principal intento de descimento ser a conversão... (Idem, p. 118).

Esse trabalho de convencimento efetuado pelos padres era considerado uma maneira menos traumática de conseguir mão-de-obra indígena do que a violência empregada pelos militares e colonos. Mas, como demonstra Corcino Medeiros, nos aldeamentos ou reduções - locais para onde eram levados os índios -, apesar de serem ele os únicos produtores, não se tornavam donos dos bens produzidos e nem de sua distribuição: 
Os indígenas recolhiam as famosas drogas do sertão, realizavam as pescarias, produziam alimentos nas roças, essências medicinais, peças de artesanatos, construíam as igrejas e residências dos missionários, construíam e remavam as canoas, etc; e, em troca do seu trabalho, recebiam a mísera quantia de duas varas de pano por mês ou apenas a alimentação, que era péssima. Essa produção devia beneficiar e somente beneficiava os padres missionários ou a sua ordem (1998, p. 81-2).

Os aldeamentos missionários obedeciam a uma certa tipologia, que pode ser assim descrita: aldeias do serviço das ordens religiosas, cuja renda revertia para as mesmas ordens, como complementação da dotação que lhes fornecia o Estado; aldeias do serviço real, onde os índios aldeados eram utilizados estritamente para o serviço do Estado; aldeias de repartição, cuja mão-de-obra era destinada aos moradores; e finalmente as missões afastadas dos núcleos urbanos que, embora sofressem desfalque e população devido à demanda das expedições, eram unidades autônomas de produção (Leite, 1938, p. 97).

Como aponta João Lúcio Azevedo, os índios

trabalhavam para o sustento próprio e manutenção das aldeias; trabalhavam para os missionários; trabalhavam para o Estado e trabalhavam para os particulares, a quem se repartia. Assim, nas aldeias era disfarçada a mais dura escravidão com o título de falsa liberdade, já que não eram legalmente reconhecidos como escravos (1901, p. 79).

As ordens religiosas recebiam constantes determinações por parte do Estado português para que concentrassem índios em suas missões, devido principalmente ao grande interesse na mão-de-obra indígena. A atividade dos descimentos, portanto, para a Coroa, deveria ser uma constante entre os missionários. Uma carta do rei de Portugal datada do ano de 1713, enviada ao Comissário Geral das Mercês mostra tal obstinação por parte do Estado:

Faço saber a vós Superior das Missões de Nossa Senhora das Mercês, por ser informado que as Aldeias da repartição desse Estado se acham muito faltas de índios para acudirem as obrigações a que estão sujeitos, vos encomendo muito mandeis fazer descimentos pelos missionários da vossa administração todos os anos, para que nesta forma haja índios bastante para o meu serviço, e dos moradores, como são obrigados, o que é de grande utilidade (BN, Vol.66, p. 95).

Devido algumas vezes à insistência da Coroa, particularmente em relação aos mercedários, na obtenção de índios em suas missões, o Comissário Geral da Ordem 
tinha que se justificar perante o rei, expondo os motivos de, muitas vezes, estarem as missões mercedárias com carência de índios. Em resposta a uma carta do rei de Portugal, o Comissário Manoel Correa Pestana afirmou que a falta de índios nas missões devia-se ao fato das muitas mortandades e também por "se extraviarem no serviço das tropas de sua Majestade”. O superior mercedário citou em sua carta o impressionante exemplo de que, em uma oportunidade, dos cento e quarenta e cinco índios levados de uma missão mercedária, somente três acabaram retornando (NA, 231, Vol. 3, p. 28).

As rivalidades entre as ordens religiosas sempre vinham à tona na Amazônia. $\mathrm{O}$ diferente posicionamento das ordens, principalmente ao que se refere à questão da mãode-obra indígena, era um fato que acirrava a rivalidade e também estabelecia as singularidades de cada ordem.

O posicionamento dos jesuítas, no período em que Antônio Vieira esteve à sua frente no Maranhão, foi incisivo em relação às demais ordens. Com referência aos descimentos, o padre Antônio Vieira também teceu considerável critica ao religioso mercedário, Antônio Nolasco:

Só com o Capitão João de Bettencur foi o padre Fr. Antônio Nolasco, o qual sendo religioso mercenário,* cuja profissão reunir cativos, ia nesta tropa a fazer, como fez, grande quantidade de escravos; porque só a sua parte trouxe trinta e cinco, e os vendeu publicamente e outros jogou e ganhou aos oficiais e soldados da tropa, sobre que anda pleito em juízo [...] Além destas causas de nulidades, e outra de maior violência que se calam, o dito padre não sabe a língua geral da terra, a qual era necessária para entender os intérpretes (1992, p. 10).

Segundo o também padre jesuíta, Bethendorf (1910, pp.204/212), na missão do Urubu o religioso mercedário, padre Theodósio da Veiga, contava com 20 escravos comprados com a permissão do Comissário Geral, no objetivo de “defendê-lo no trabalho das missões”. Fato também curioso, na medida em que a ordem das Mercês se apresentava “redentora de cativos”. Infelizmente, o cronista jesuíta não deixou claro o papel destes escravos no trabalho catequético de frei Theodósio, nem mesmos se eram negros ou índios.

David Sweet (1974, pp. 626-680) argumenta, em relação aos carmelitas, que desenvolveram missões no rio Negro e Solimões. Diferentemente dos jesuítas do período, os carmelitas, segundo o autor, não tinham um projeto próprio quanto à administração da mão-de-obra indígena: ao contrário, suas missões tornaram-se centros 
de suprimento de mão-de-obra para os moradores, no mais das vezes em franco descumprimento das exigências legais. Além disso, segundo o autor, os missionários individualmente se engajaram no comércio regional, inclusive no tráfico clandestino de índios escravos.

Os mercedários também não parecem ter desenvolvido esforços maiores para a permanência ou proteção de índios em suas missões. Em carta, o comissário geral da ordem à missão do rio Urubu recomenda a seus religiosos que "se viessem colonos a procura de índios nas imediações da dita missão que os religiosos dessem permissão para procurarem por cinco dias os índios requeridos. No caso de estarem a serviço do rei poderia ser concedido um tempo maior para a busca”. (AN, vol. 3, p. 26) Mercedários e carmelitas, portanto, quanto ao aspecto de proteção dos índios em suas aldeias, se comparados aos jesuítas, parecem ter apresentado outro tipo de postura frente às pretensões estatais e dos colonos, muitas vezes os auxiliando.

Quando encerrada a fase em que Antonio Vieira esteve à frente dos jesuítas, defendendo com profundo fervor a liberdade dos índios, instaurou-se um período que Moreira Neto intitula de "fase empresarial das missões jesuíticas”. O resultado final, segundo o autor, foi a missão jesuítica ter tomado características empresariais, tão comprometida com as operações de produção, comércio e lucro de seus estabelecimentos quanto qualquer outra agência econômica colonial. Ironicamente, os jesuítas passaram a ser liderados, nessa nova fase ou concepção no Brasil, por dois antigos auxiliares de Vieira: os padres Jorge Benci, autor da Economia Cristã dos Senhores no Governo dos Escravos, editado em 1705, e João Antônio Andreoni, o Antonil de Cultura e Opulência do Brasil por suas Drogas e Minas, 1711 (Moreira Neto, 1992, p. 69).

Antonio Vieira teve a preocupação, como visitador, entre os anos de 1688 de 1691, de elaborar um Regimento das Aldeias que vedava aos reitores dos colégios servirem-se do trabalho dos índios, ainda que remunerado, para prevenir abusos que dessem margem a suspeitas sobre a lisura da ação catequética. Antonil, designado provincial (1698), solicitou ao padre geral dos jesuítas que a lei fosse revogada. Segundo o padre jesuíta, "se os senhores de engenho se valiam do índio, por que só os religiosos não poderiam faze-lo?”. (Bosi, 1992, p. 154)

Com referência à utilização de índios como escravos nos conventos ou fazendas dos religiosos, carmelitas e mercedários, pelo que parece, detinham a mesma concepção 
de Antonil. É o que demonstra um documento datado de 1727, em que o rei de Portugal concedeu a cada ordem de religiosos mercedários e carmelitas quatrocentos casais de índios, dados como “resgatados” e, portanto, “merecedores da escravidão”. A doação foi feita após petições elaboradas pelos vigários principais dos mercedários e carmelitas, que alegaram "a necessidade em que se acham os conventos de escravos, por conta do rigoroso estrago que se fez com o contágio de bexigas” (BN, Vol. 02, p. 190).

\section{CONSIDERAÇÕES FINAIS}

Mesmo que em determinados momentos tenha havido uma preocupação por parte de alguns religiosos inseridos no projeto de colonização em “proteger o índio”, este teve que ingressar obrigatoriamente nas pretensões dos colonos. Restaram-lhe as opções do confronto, da fuga, ou da conivência, todas prejudiciais a ele.

A mão-de-obra indígena foi de fato elemento preponderante para expansão do império português na Amazônia, para o desenvolvimento comercial dos colonos, como também o das ordens religiosas. Estas, como visto, com o seu trabalho catequizador implementaram a atividade de trabalho do índio ao modelo mercantil, buscando o lucro e o acúmulo de capital, da mesma maneira que faziam os colonos ${ }^{1}$.

Com relação á historiografia, esta ainda não tomou a devida atenção ao estudo da região norte no período colonial, dando ênfase aos “ciclos econômicos”: nordeste e sudeste. A grande maioria de nossos clássicos quase não tomou conhecimento da existência do vasto território, renegando-o a posição de núcleo isolado e periférico.

\section{NOTAS}

* James O. Sousa é mestre em História pelo Programa de Pós-Graduação em História da Universidade de Brasília.

${ }^{1}$ Os frutos econômicos que as ordens religiosas puderam usufruir com a mão-de-obra indígena, em especial dos mercedários, meu objeto de estudo no mestrado, foram expostos no terceiro capítulo de minha dissertação, citada na referência bibliográfica do presente textos, enfatizando o acúmulo patrimonial dos missionários, em grande parte construído à custa do trabalho, da exploração e da vida dos indígenas que deveriam proteger. 


\section{FONTES IMPRESSAS}

Anais do Arquivo Publico do Pará. Códice 231,vol. II, p. 130.Relação dos Índios aldeados no Estado do Grão-Pará e Maranhão efetuada pelo governo do Estado em 12 de março de 1720.

Anais da Biblioteca Nacional. Livro Grosso do Maranhão. Vol. 66, parte 1, 1948.

\section{FONTES MANUSCRITAS}

Arquivo Nacional, Códice 231, Vol. 3, p. 28. Resposta do Comissário Geral da Ordem de Nossa Senhora das Mercês ao rei de Portugal em 18 de agosto de 1723.

Arquivo Nacional, Códice 231, Vol. 3, p. 26. Carta do Comissário da Ordem de Nossa Senhora das Mercês a missão do Urubu em 05 de janeiro de 1703.

Arquivo Nacional, Códice 231, Vol. 3. p. 32. Resposta de uma carta do rei de Portugal feita pelo Comissário Geral da Ordem de Nossa Senhora das Mercês. Pará 18 de agosto de 1723.

Biblioteca Nacional do Rio de Janeiro, Grão-Pará, 21. 1. 1, número 10. Memória sobre as causas da diminuição dos Índios do Estado do Pará.

Arquivo Histórico Ultramarino. Pará, caixa 111 Relação das vilas do Estado do Grão-Pará (sem data).

\section{REFERÊNCIAS BIBLIOGRÁFICAS}

ALMEIDA, Rita Heloisa de. O Diretório dos índios: um projeto de civilização no Brasil do século XVIII. Brasília, Edunb, 1997.

AZEVEDO, João Lúcio de. Os jesuítas no Grão - Pará - suas missões e a colonização. Lisboa, Tavares Cardoso e Irmão, 1901.

BEOZZO, José Oscar. Leis e regimentos das Missões - Política Indígenista no Brasil. São Paulo, Edições Loyola, 1984.

BETENDORF, João Felipe. Chronica da Missão dos Padres da Companhia de Jesus no Estado do Maranhão in: Revista do Instituto Histórico Geográfico Brasileiro, Tomo LXXII, parte I. Rio de Janeiro, Imprensa Nacional, 1910.

BOSI, Alfredo. Dialética da Colonização. São Paulo. Cia. das Letras, 1992.

CARDOSO, Flamarion S. Economia e Sociedade em Áreas Econômicas Periféricas. Rio de Janeiro, Graal, 1984.

CEHILA. História da Igreja no Brasil Tomo II/1. Petrópolis, Vozes, 1992.

. “Os movimentos missionários” in Hoornaert, Eduardo. História da Igreja no Brasil. Tomo II/1, Petrópolis, Vozes, 1992.

CUNHA, Manuela Carneiro da. Os direitos do índio. São Paulo: Brasiliense, 1985.

DUSSEL, Enrique. "As reduções: Um modelo de evangelização e um controle hegemônico" in Hoornaert (org). Das Reduções Latino-Americanas ás lutas indígenas atuais. São Paulo, Vozes, 1982.

FARAGE, Nadia. As muralhas dos Sertões - Os povos indígenas no rio Branco e a colonização. Rio de Janeiro: Paz e Terra: ANPOCS, 1991.

FRAGOSO, Hugo. "A era missionária (1686 - 1759)" in Hoornaert (org) História da Igreja na Amazônia. Petrópolis, Vozes, 1992.

FURTADO, Francisco Xavier de Mendonça. Diretório que se deve observar nas povoações dos índios do Pará, e Maranhão enquanto sua Majestade não mandar o contrario. Lisboa, Oficina Miguel Rodrigues, 1758. 
HANDELMANN, Heinrich. História do Brasil - Tomo I, Rio de Janeiro, Imprensa Nacional, 1931.

LEITE, Serafim. História da Companhia de Jesus no Brasil. Tomo IV. Rio de Janeiro, Instituto Nacional do Livro, 1938.

LEONARDI,Victor. Entre Árvores e Esquecimentos. História Social nos Sertões do Brasil. Brasília, Paralelo 15, 1996.

2000.

Os Historiadores e os Rios - natureza e ruína na Amazônia brasileira. Edunb/Paralelo 15, Bsb,

MAXWELL, Kenneth. Marquês de Pombal: paradoxo do Iluminismo. Cia. das Letras, São Paulo, 1996.

MOISES, Beatriz Perrone, “Os princípios da legislação indígenista do período colonial” in Da Cunha (org.) História dos İndios no Brasil. São Paulo, Cia das Letras, 1992.

MONTEIRO, John Manuel. Negros da Terra: índios e bandeirantes nas origens de São Paulo.Companhia das Letras, 1994.

MOREIRA NETO, Carlo de Araújo. “Os principais grupos que atuaram na Amazônia Brasileira entre 1607 e 1759.” História da Igreja na Amazônia. Editora Vozes, Petrópolis, 1992.

PORRO, Antônio. "História Indígena do Alto e Médio Amazonas (séculos XVI /XVII) in Cunha, Manuela Carneiro da. (org.) História dos Índios no Brasil. São Paulo. Cia das Letras, 1992.

SANTOS, Corcino Medeiros dos. Amazônia: conquista e desequilíbrio do ecossistema. Brasília, Thesaurus, 1998.

SWEET, David. . Rich Realm of nature destroyed: The middle amazon valley. Wisconsin. University of Wisconsin, tese de PhD, 1974, Volume II.

SOUSA, James O. Religião, Estado e Escravidão na Amazônia Colônia - A atuação da Ordem de Nossa Senhora das Mercês (1640-1794). Brasília, UnB, 2000.

THOMAS, Georg. A Política Indigenista dos portugueses no Brasil 1500 - 1640. São Paulo, Loyola, 1981.

VIEIRA, Antônio. Cartas. São Paulo, Livraria Magalhães, 1912.

. Escritos Instrumentais sobre os índios - São Paulo, Educ/Loyola/Giordano, 1992. 